Article

\title{
Building Consensus with Local Residents in Community-Based Adaptation Planning: The Case of Bansong Pilbongoreum Community in Busan, South Korea
}

\author{
Donghyun Kim $₫$ and Jung Eun Kang * \\ Department of Urban Planning and Engineering, Pusan National University, Busan 46241, Korea; \\ donghyun-kim@pusan.ac.kr \\ * Correspondence: jekang@pusan.ac.kr
}

Received: 31 October 2019; Accepted: 16 February 2020; Published: 19 February 2020

check for updates

\begin{abstract}
Climate change adaptation is challenging in community planning because of the conflict between planners' scientific knowledge and residents' local knowledge. Focusing on the Bansong Pilbongoreum community in South Korea, we suggest a community-based adaption plan that uses local knowledge and builds consensus between local residents and planners by identifying problems and planning objectives. We applied this plan to our case study, using in-depth interviews, a community workshop, local knowledge, and scientific climate adaptation measures to identify the community's problems and develop a plan. Planners and residents must communicate so that planners can incorporate local knowledge into effective planning objectives for community adaptation.
\end{abstract}

Keywords: local knowledge; community-based adaptation; community planning; participatory planning; consensus building

\section{Introduction}

Recently, many studies have emphasized the need to incorporate local knowledge in planning and decision-making processes. Following the anti-modernization critiques of technology paradigms [1] in the latter half of the 1960s, discussions that emphasized consensus building and learning processes [2], as well as those that reflected insight and firsthand situational experience in planning [3], began appearing in a variety of forms.

Effective community collaboration requires consideration of local knowledge, particularly when identifying and scoping out environmental issues. Local knowledge is useful in the "joint fact-finding" approach, because it is derived from individuals who have closely encountered environmental issues in their community [4-7]. This approach dictates that, in order to solve a problem, one must establish an investigative scope and collect information based on that scope [8-10]. Local knowledge is also beneficial for developing policy measures that will impact communities [11].

Recently, discussions about local knowledge in relation to climate change adaptation have increased. Communities are being recognized as a major source of adaptation. Thus, there is a need to incorporate indigenous, local, and traditional knowledge systems and practices into adaptation planning to holistically adjust to the effects of climate change [12]. Community-based adaptation programs strengthen social resilience within communities, better integrate efforts to reduce risk against extreme weather events, and make climate change adaptation possible [13]. Communities' local knowledge can help us understand the effects of climate change on a local scale. There are limitations to global climate models due to interpolation problems when downscaled and uncertainties in weather coverage [14,15]. Planners and policymakers can integrate scientific knowledge with location-based 
details and observations provided by people in the community to understand the effects of climate change and resolve uncertainties on a local scale [16-19].

The purpose of this study is to test a three-step process for drawing local knowledge from community residents and building consensus between local residents and planners in creating community-based adaption plans. The three-step process comprises understanding local conditions, building consensus with locals, and mining local knowledge, representing early phases of the planning process. We apply these processes to the practical case of the Bansong Pilbongoreum community in Busan, South Korea. The paper's first section reviews existing theories on local knowledge and participatory planning processes. Next, we introduce the three-step process for developing communities' planning objectives, described above. The third section describes how we applied these three steps in the case study of the Bansong Pilbongoreum community. Finally, we discuss the implications of creating community-based adaptation plans using local knowledge.

\section{Theoretical Discussion}

\subsection{Definition and Characteristics of Local Knowledge}

There are several specific definitions for local knowledge within a diverse range of fields, but essentially, this type of knowledge is based on local context or practices and possesses commonalities that are collectively embedded in experiential information [20-24]. Having a local-context foundation suggests that this knowledge type is informed by location-based values, situations, and relationships [20,25]. Being collectively embedded in experiential information means that local knowledge may be encapsulated by certain social interactions [21] and relevant to the community through its social construction, accumulation, and transference. These qualities make local knowledge difficult for outside experts to attain [26].

The characteristics of local knowledge have been compared with the scientific knowledge of professional groups [20]. Lundvall and Johnson [27] argued that scientific knowledge includes the principles and theories underlying observable phenomena, while local knowledge can be deduced through observation and experience and is more tacit, implicit, and context-dependent. A community's local knowledge is bound by geography and identity. In contrast, professional knowledge is unbounded, as it can be possessed by various groups, including professionals, universities, government agencies, and industrial associations [20]. One way in which professional knowledge distinguishes itself from local knowledge is through its process for gathering evidence. Professional knowledge is regarded as objective, verifiable, and something that can be tested using accepted methodologies [7]. In comparison, the evidence that supports local knowledge is attained through common sense and historical or daily experiences $[7,28]$, and is verified by images, pictures, oral storytelling, or narratives $[29,30]$. Local knowledge is not a simple hunch or spontaneous intuition, as the evidence is subjected to its own testing process based on repeated experiences and observations [20]. In addition to experiences, social and cultural values, norms, and institutions are included in local knowledge [31]. Corburn [20] explained that claims formed through local knowledge are divided into two types: contextual knowledge, in which local problems are identified; and the observation of facts and considering their causes to build a hypothesis.

\subsection{Participation and Local Knowledge}

Incorporating the characteristics of local knowledge into a community plan can be achieved by allowing stakeholders, who have local knowledge, to participate in the plan development. This participation is an essential part of the embedded process necessary for building a consensus in decision-making using local knowledge [2]. Participation types for decision-making are categorized based on the participants' characteristics, roles, and decision-making empowerment level. Arnstein [32] argued that participation levels range from passive dissemination, which falls under manipulation, to active engagement, which falls under citizen control. Biggs [33] classified participation into contractual, 
consultative, collaborative, and collegiate types, each based on the participants' levels of engagement in the decision-making process. Rowe and Frewer [34] categorized participation types based on the flow of communication between participants-consultation pointed to the act of simply seeking to obtain information, whereas two-way communication signified a mutual exchange of information. Lawrence [35] also identified transformative participation, which empowers participants to elicit community transformation.

When meeting local needs and priorities, policy intervention and technologies can be applied and adapted to local socio-cultural and environmental conditions [36,37]. Furthermore, including local interests in the early stages of development can elicit a variety of ideas and perspectives for future action, which can increase the project's ability to satisfy local needs and priorities [38]. Allowing locals to participate enhances the quality of decisions and the ability to foresee unexpected negative impacts $[24,39,40]$. When a broad coalition of stakeholders participates in the decision-making process, the plan or policy achieves long-term support, which makes active implementation possible and decreases implementation costs [41].

In spite of these benefits, a number of studies have revealed that both scientists and government officials have been reluctant to consider local sources of knowledge [42,43]. Central agencies continue to rely on accepted scientific practices and are not yet prepared to consider alternative knowledge sources [44]. The physical and structural measurements of scientific knowledge are predominantly reflected in public policies, while aspects of local knowledge have largely been dismissed [45]. Innes and Booher [5] discussed the concept of "epistemological anxiety" regarding passive tendencies in the application of local knowledge. This anxiety arises from professionals' various views on determining the validity of knowledge and, thus, determining which knowledge should be incorporated [4]. Essentially, when opposing knowledge types (professional and local) deliberate, their differing skills and knowledge hamper the discussions [46,47]. These opposing epistemic positions create uncertainty for planners and scientists when trying to reach a decision [48]. As a result, because these professionals perceive local knowledge as insufficient expertise, trust in information declines overall [49].

\subsection{Planning Process and Methodology to Incorporate Local Knowledge}

It is possible to overcome epistemological barriers between local residents, the public, stakeholders, planners, policymakers, and scientists through a structured participatory process and a participatory method. The planning field emphasizes the use of socially embedded practices to proactively engage the public and interactively plan with community groups to develop nonprofessional knowledge [3,50]. Due to the recognition that incorporating local knowledge into policy can be difficult, planners have discussed the need for an interpretative framework that incorporates the different structures and types of knowledge [50,51].

An interpretative framework for planning consists of a structure that can be modified according to the interests of participants. Healey [52] stressed that collaborative planning with involved participant interaction was a process that transformed knowledge and values into action. Foster [53] argued that, with regard to incorporating local knowledge into planning practice, problem-recognition was more important than problem-solving. Framing or structuring a community's circumstances means using their knowledge to express and resolve problems while seeking to understand their beliefs and perceptions [54]. An interpretative framework reflects local insights and interpretations of planning techniques and solutions, which can subsequently be expressed in the planner's proposal [50]. Implementing such a framework during the interactive planning process makes it possible to understand a community's needs and preferences with respect to their living environment [55-57].

Beyond the interpretative framework, additional ways to incorporate local knowledge into the planning process include various methodologies that combine a specialist's knowledge with contextual knowledge [20,50]. Van Herzele and Van Woerkum [3] suggested that planners must employ a method of visualization in order to combine community values and expert knowledge. This method is useful in that images have the ability to encapsulate a variety of perspectives, perhaps more effectively than 
words $[58,59]$. However, there are limitations to this method, including limited access to and ability to use visualization tools, as well as the potential to inadequately express some pieces of information visually [60].

\subsection{Climate Change Adaptation and Local Knowledge}

Climate change adaptation considers local knowledge in conjunction with spatial planning knowledge, an important factor for mainstreaming climate change adaptation that emphasizes a place-based approach, taking into account geographic variability in the process $[61,62]$. Such a place-based approach means that spatially-embedded characteristics should be reflected in the planning process [63]. Even within the same space range, there may be differing characteristics of vulnerability, depending on factors such as income, infrastructure conditions, and housing conditions [64]. Therefore, the spatial planning process for climate change adaptation aims to identify these factors, along with local knowledge [63].

In climate change adaptation, local knowledge includes both climate change impacts and non-climate-related socioeconomic conditions $[65,66]$. In particular, it highlights a wide range of stakeholders and participants to enable them to integrate the various objectives of community space planning with adaptation to climate change [67]. This means that climate change adaptation based on communicative rationality can be prepared through the process of mutual sharing, learning and participation in community issues [68]. The use of participatory methods identifies causal mechanisms for climate change within the community, and integrates scientific and local knowledge to enable adaptation learning, planning and effective implementation [69]. This means that information on the risks of climate change should be prepared to share with community members, based on participatory processes and communication rationality [68]. This process not only enables the integration of local knowledge into scientifically based results, but also enables the elicitation of behavioral changes that lead to adaptation to solve practical problems [70-72].

\section{Materials and Methods}

Existing discussions on collaborative planning in community-based adaptation have emphasized the way local knowledge can be used in practical decision-making, as well as the participatory tools available for those processes [73]. However, despite the numerous advantages of collaborative planning, planners encounter many difficulties in its application, such as disinterest among residents, low capacity, unfamiliarity with climate change adaptation concepts, and, most importantly, the lack of consensus and trust among residents, stakeholders, and planners. This lack of trust arises from planners' prior failures to implement policies that actually reflect the community's behaviors and needs [74].

Using an interpretative framework to conduct community planning helps planners avoid conflict, reduce cynical residential reactions, and elicit local knowledge to better understand local conditions before moving toward the decision-making process. In this research, we employed processes to understand local conditions and build a consensus with local residents in order to mine local knowledge and garner support for community planning embedded with climate change adaptation. We utilized a three-step process to identify local knowledge from local residents for community planning with climate change adaptation, shown in Figure 1. 
Step 1: Understanding Local Conditions

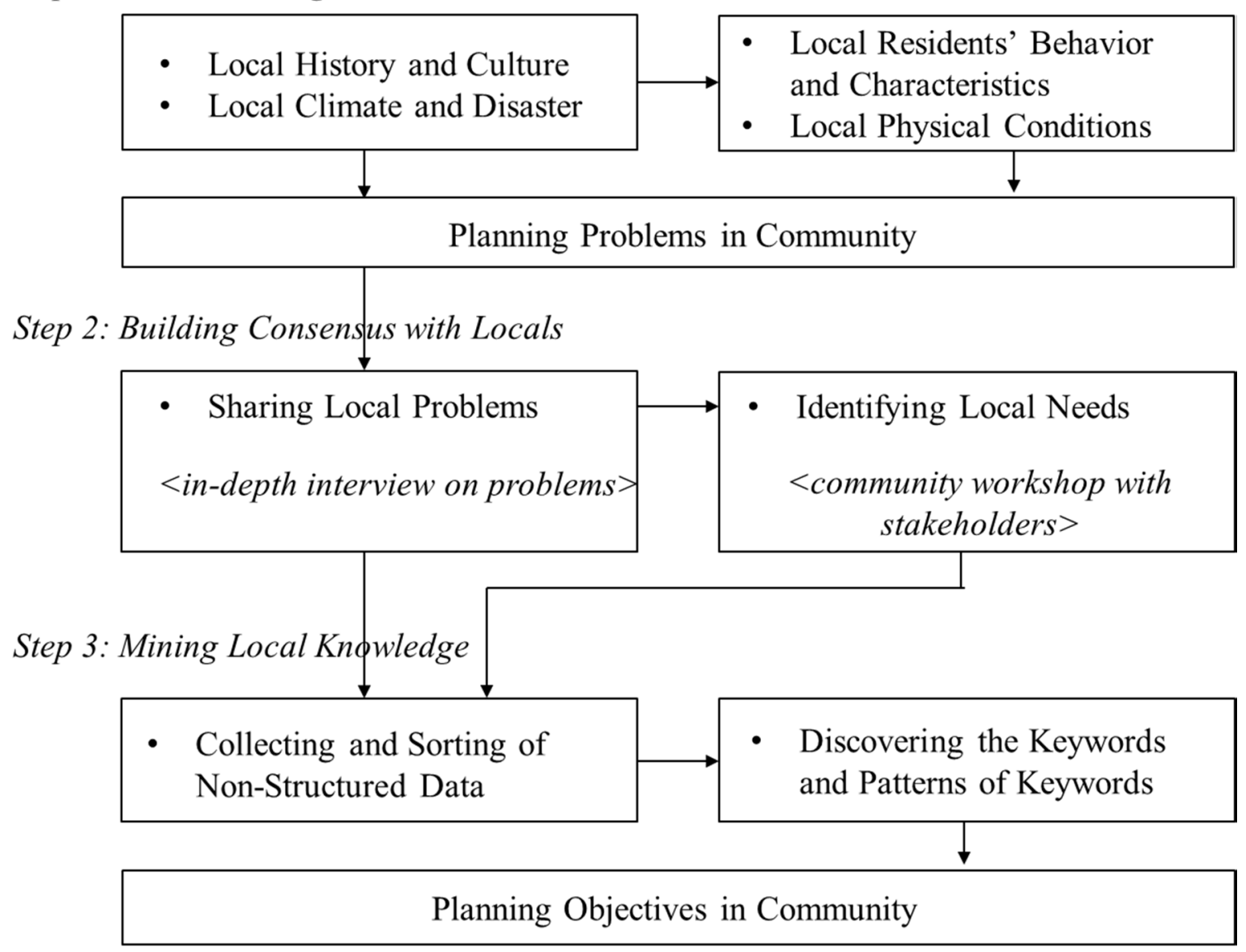

Figure 1. The three-step process to discover local knowledge.

The first step for planners is to understand the four categories of local conditions: history and culture, climate and disaster, residents' behavior and characteristics, and physical conditions. Through literature reviews, field investigations, interviews, etc., planners can enhance their understanding of communities and their problems. Interviews and literature reviews with diverse data sets are best for learning local history and culture, while local statistics and media data are best for discovering local climate and disasters. As a follow-up, planners complete community field investigations to better understand the climate, residents' behavior and characteristics, and the physical conditions. Thus, planners may experience some planning problems in these areas while conducting their research.

The key processes at this stage are field investigation and interviewing. Prior to climate adaptation planning by the community, the aim is to establish a trustful relationship with local residents and empathizing with them on local community-oriented issues. Field investigation and interviewing focus on identifying local problems in community. Field investigation is conducted for all areas in the community and includes seeking answers to the following questions: What are the risks facing the local community? What is the behavior of people (movement, rest, and local activities)? What is uncomfortable in the living environment? What causes these inconveniences? What areas have experienced flooding and runoff of stormwater in the past? Where is heat affected? Where can heat be avoided? Field interviews involve multiple residents at all points where investigations are conducted; it does not use structured or prepared questionnaires, but focuses on hearing residents' views about local problems. In addition, through interviews with local residents, the key stakeholders in the community are identified. Through this process, it is possible to organize where problems occur in the community and how they affect the residents, and the contents of problems identified through community maps, photos of the site, interviews and field surveys. 
Next, planners build a consensus with locals to elicit local knowledge about the conditions discovered in the first step. This step consists of sharing local problems and identifying local needs. Planners can reach a consensus with community members on what the local problems are by conducting interviews with locals and sharing problem recognition. Then, planners identify local needs; that is, they identify what local stakeholders want with regard to the problems shared earlier. For this, planners coordinate community workshops in which they avoid expressing opinions or solutions and instead listen to residents' discussions about community problems and needs. To best grasp the local stakeholders' needs, planners use a community map for residents to explain the locations of their most significant needs and problems.

The key processes at this stage are in-depth interviews and community workshops. In-depth interviews are conducted using the results from the first stage. The interview subjects in this round are those who are clearly aware of the problems identified in the previous round, as well as the residents who gave specific opinions, those who did not interview in the first stage, and the stakeholders identified in the first stage. The situation and problems identified and summarized in the first stage are presented to participants in this round, and the interview is aimed at uncovering more specific problems related to the problem, the cause of the problem, and the complex community issues related to the climate situation. Community workshops are conducted after each individual interview. A group discussion is conducted on the community issues uncovered during both rounds of interviews, and the stakeholders identified in step 1, focusing on how the community members relate to heat waves, heavy rain, and so on. The community workshop focuses on the problem itself, rather than on resolving it. In this process, the planners do not directly enquire about the local impact of climate change, climate change adaptation, or climate change in general, as this can hinder participation in developing community plans. Many people are unfamiliar with the realities of climate change; instead of the term climate change, planners use more layman-friendly and related terms, such as "heat wave," "hot weather," "heavy rain," or "rainstorm."

Finally, planners mine local knowledge by converting the information gleaned from problem sharing and the needs identified into structured information. We used the content analysis method, based on the Kim et al. [75,76], to analyze all interview and workshop data. Through content analysis, planners extract keywords from residents' and stakeholders' interviews and workshops. When deducing keywords from speech, analogous terms are grouped together, and keywords presented in equivalent contexts are connected and grouped. Keywords are grouped according to various relationships such as cause and effect, order, and parallels. The results obtained become local knowledge, which, from a planner's perspective, reveals the objectives that their community planning should resolve. In this process, we review the conversations that occurred during resident interviews and community workshops through a process of clustering analogous terms. We selected only keywords that had been mentioned at least three times; if those words were used in a similar context, they would be grouped together. Then, we made connections between the keywords.

\section{Results}

\subsection{Understanding Local Conditions}

\subsubsection{Local History and Culture}

In this research, we gathered bibliographic data to understand the historical process and culture under which the Bansong Pilbongoreum community was built. We collected the data, which included policy settlements in the Bansong community and the Busan area, by searching the Korean media database BIGKinds (http://www.bigkinds.or.kr) and the academic database RISS (Research Information Sharing Service) (http://www.riss.kr).

We examined the target area's history and culture using various resources. The Bansong area is located in the northern part of Haeundae-gu, Busan [77]. The Bansong area is divided into upper Bansong and lower Bansong. The Bansong Pilbongoreum community is located in Bansong 3 dong of 
the lower Bansong area. The government developed the lower Bansong area as a policy settlement for citizens evicted during a slum urban redevelopment phase that occurred as a result of the Korean War [78-80]. In 1968, the local government created plots of land through a land readjustment project and sold those lots to citizens as home building sites $[79,80]$. The area was developed with streets in a grid network, which still exists today [81].

However, by providing only land plots for a largely low-income community, other problems arose, such as deteriorating housing and slums. In 1989, the government passed the Act on Temporary Measures for Improving Dwelling Conditions for the Urban Low Income Class, which resulted in private-led reconstruction. In order to induce this private-led reconstruction, the Act loosened construction laws that had regulated height limits and the ratios of buildings to land and floor areas. Parking lot construction requirements were exempted, building material quality was no longer applied, and light intensity was lowered to $50 \%$ of the original standard. Although the area lacked the urban infrastructure to support the increased population, this multi-family home reconstruction rapidly increased the residential density rate. This area still suffers from urban infrastructure issues, such as a lack of parking and parks [80,82].

The Bansong area also suffers from social prejudices due to its lack of infrastructure, deteriorating buildings, and its residents' low socioeconomic status. In response to this, community activities to overcome these prejudices have been implemented [77,79]. These activities are primarily focused in lower Bansong. With the inception of the program "A Meeting for People Who Love Bansong" in 1998, small groups continue to meet for a variety of activities and even compose a town newsletter [77]. The communities in the Bansong area conduct their social and economic activities at a central market [78,79]. After facing an onslaught of various opposition movements against unwanted public facilities, the local residents rallied together and built a greater self-awareness, as well as a sense of solidarity within their community. These efforts progressed into the development of a full-fledged community $[77,79]$. The sense of solidarity grew among local residents as they jointly opposed industrial waste landfills, crematorium construction, and supermarket locations [79]. Additionally, leaders of the community banded together with other groups in the area and expanded organizations within the community. This diverse participation and community action continue today [77]. The growth of participative community action in the Bansong area is founded on a sense of social accomplishment among residents, the construction of trusting relationships in which individuals can share their problems, and efforts to expand residents' personal interest in encapsulating the community in which he or she lives [83].

\subsubsection{Local Climate and Disasters}

To understand the local climate and disasters in the Bansong area, this study used the 2015 Korea Meteorological Administration and Busan Regional Office of Meteorology's analytical report on climate change in Haeundae-gu of the Busan metropolitan area [84]. In addition, this study reviewed local newspaper articles on disaster-related damage after the year 2000.

According to the report on climate change [84], the annual number of tropical nights was 7.8, and the number of extreme heat days was 6.7 in 2010. Based on a Representative Concentration Pathways (RCP) 8.5 scenario, predictions for the years 2071-2100 show that the number of tropical nights and extreme heat days will increase to 75.2 and 55.1, respectively. Also, based on the RCP 8.5 and 4.5 scenarios, the average temperature increase in Bansong 3-dong is the greatest in Haeundae-gu. Bansong 3-dong's annual precipitation for 2010 was $1665.7 \mathrm{~mm}$, higher than Haeundae-gu's average of $1570.4 \mathrm{~mm}$. According to the RCP 8.5 scenario, annual precipitation predictions for Bansong 3 dong between 2091 and 2100 are expected to reach $2592.9 \mathrm{~mm}$ and will be the highest within Haeundae-gu. Precipitation intensity, which was $20.4 \mathrm{~mm}$ per day in 2010 , will increase to $25.7 \mathrm{~mm}$ per day between 2071 and 2100, and the number of heavy rain days will increase to 5.8 days in that same time frame, up from 3.4 days in 2010. The local press reported four cases of disaster-related damages after 2000. Stream flooding resulting from heavy rains led to lowland flood problems, and heatwaves created elevated risks for the area's dilapidated housing, elderly health, heat-related diseases, and even death [79,85-87]. 


\subsubsection{Local Residents' Behaviors and Characteristics}

We conducted a field investigation over the course of several days, from May 3 to May 11, 2014, to identify local residents' behaviors and characteristics associated with the local climate and disasters. Behaviors and characteristics examined in relation to heatwaves included the main pedestrian paths taken by local residents, behaviors of the disadvantaged, and locations of rest areas. The lowland flood areas and storm-water runoff were linked to heavy rain. The results are displayed in Figure 2 and Table 1.

A heatwave did not occur during the investigation, but the highest day temperatures were between $25^{\circ} \mathrm{C}$ and $27^{\circ} \mathrm{C}$, compared with an average daily high of $21.7{ }^{\circ} \mathrm{C}$, making it possible to extrapolate behaviors related to heatwaves. The investigation confirmed that an area of eight meters around a road that passes through the community was exposed to heatwave dangers. A high density of local residents, heat from the outdoor units of air conditioners installed in shopping areas, heat from vehicles, narrow walking areas without shade from trees, and asphalt pavement were all factors that increased the heatwave dangers. As reported by the local press, rest areas for extreme heat were not easily accessible for the elderly population. Rest areas for the elderly and play areas for children were typically in areas between homes, where there was traffic. Notably, areas adjacent to a mountain were relatively cooler because of mountain winds flowing from the uplands to the lowlands.
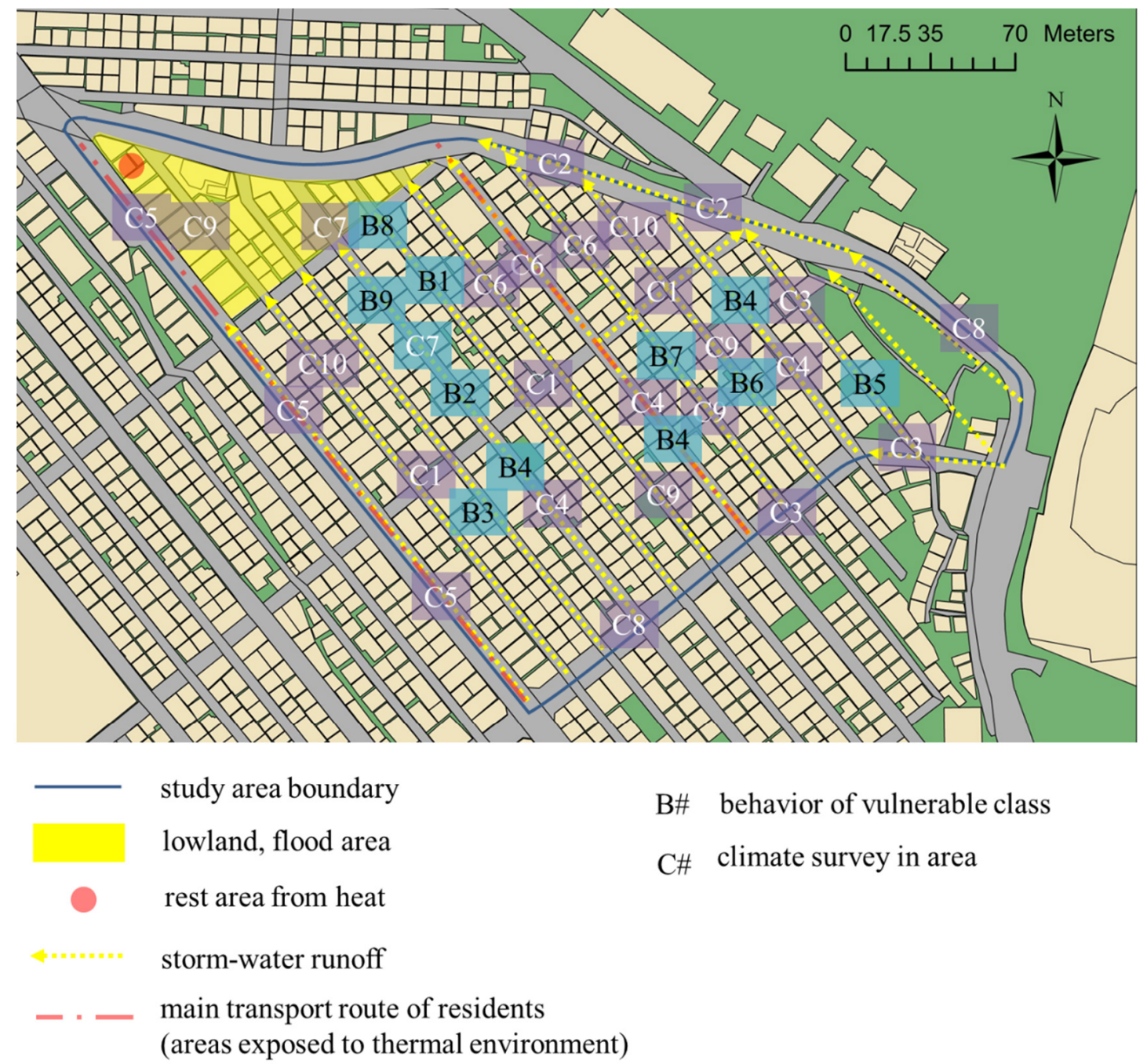

Figure 2. Field investigation of local residents' behaviors and characteristics in the research area. 
Table 1. Behavior of the vulnerable class in the target area and climate survey in the area.

\begin{tabular}{|c|c|c|c|c|c|c|c|}
\hline Place & Target & Content & Date & Place & Target & Content & Date \\
\hline B1 & Elderly & $\begin{array}{l}\text { Road outside house } \\
\text { Relaxation in shade }\end{array}$ & $\begin{array}{l}\text { May 3, } \\
2014\end{array}$ & $\mathrm{C} 1$ & Heatwave & $\begin{array}{l}\text { Space that is not } \\
\text { exposed to sunlight }\end{array}$ & $\begin{array}{c}\text { May 3, } \\
2014\end{array}$ \\
\hline B2 & Elderly & $\begin{array}{l}\text { Holding of area } \\
\text { meetings inside the } \\
\text { market space }\end{array}$ & $\begin{array}{l}\text { May 3, } \\
2014\end{array}$ & $\mathrm{C} 2$ & Heatwave & $\begin{array}{l}\text { Relatively cool due } \\
\text { to mountain winds }\end{array}$ & $\begin{array}{c}\text { May 3, } \\
2014\end{array}$ \\
\hline B3 & Children & $\begin{array}{c}\text { Side street } \\
\text { playground }\end{array}$ & $\begin{array}{l}\text { May 3, } \\
2014\end{array}$ & C3 & Heatwave & $\begin{array}{l}\text { Relatively cool due } \\
\text { to mountain winds }\end{array}$ & $\begin{array}{c}\text { May 3, } \\
2014\end{array}$ \\
\hline B4 & Elderly & $\begin{array}{l}\text { Road outside house } \\
\text { Relaxation in shade }\end{array}$ & $\begin{array}{l}\text { May 4, } \\
2014\end{array}$ & $\mathrm{C} 4$ & $\begin{array}{l}\text { Heatwave, } \\
\text { Heavy } \\
\text { Rain }\end{array}$ & $\begin{array}{l}\text { Sunlight is blocked. } \\
\text { Water flows in same } \\
\text { direction. Foul } \\
\text { smell from drain }\end{array}$ & $\begin{array}{l}\text { May 4, } \\
2014\end{array}$ \\
\hline B5 & Children & $\begin{array}{l}\text { Side street } \\
\text { playground }\end{array}$ & $\begin{array}{l}\text { May 5, } \\
2014\end{array}$ & C5 & Heatwave & $\begin{array}{l}\text { Lots of car and foot } \\
\text { traffic, exposed to } \\
\text { heat }\end{array}$ & $\begin{array}{l}\text { May 7, } \\
2014\end{array}$ \\
\hline B6 & Children & $\begin{array}{l}\text { Side street play } \\
\text { space }\end{array}$ & $\begin{array}{l}\text { May 5, } \\
2014\end{array}$ & C6 & Heatwave & $\begin{array}{l}\text { Refreshing area due } \\
\text { to plants around the } \\
\text { home }\end{array}$ & $\begin{array}{l}\text { May 9, } \\
2014\end{array}$ \\
\hline B7 & Elderly & $\begin{array}{l}\text { Road outside house } \\
\text { Relaxation in shade }\end{array}$ & $\begin{array}{l}\text { May 7, } \\
2014\end{array}$ & $\mathrm{C} 7$ & Heatwave & $\begin{array}{l}\text { Sunlight blocked } \\
\text { due to tents on each } \\
\text { building }\end{array}$ & $\begin{array}{l}\text { May 9, } \\
2014\end{array}$ \\
\hline B8 & Elderly & $\begin{array}{l}\text { Meeting and resting } \\
\text { spaces }\end{array}$ & $\begin{array}{l}\text { May 5, } \\
2014\end{array}$ & $\mathrm{C} 8$ & $\begin{array}{l}\text { Heavy } \\
\text { Rain }\end{array}$ & $\begin{array}{l}\text { Rainwater flows } \\
\text { downward from } \\
\text { drain to road }\end{array}$ & $\begin{array}{l}\text { May 11, } \\
2014\end{array}$ \\
\hline B9 & Elderly & $\begin{array}{l}\text { Meeting and resting } \\
\text { spaces }\end{array}$ & $\begin{array}{l}\text { May 5, } \\
2014\end{array}$ & C9 & $\begin{array}{l}\text { Heavy } \\
\text { Rain }\end{array}$ & $\begin{array}{l}\text { Blocked drain due } \\
\text { to garbage. Foul } \\
\text { odors occur }\end{array}$ & $\begin{array}{l}\text { May 14, } \\
2014\end{array}$ \\
\hline
\end{tabular}

We determined that lowland flood areas and storm-water runoff were linked to torrential rain. There was a constant directional storm-water runoff from the community's highlands to its lowlands. Rainwater did not gather in drainage pipes, and most storm-water runoff followed the road down to the lowland areas. Even in communities that are virtually flat, a portion of the lowland areas also experienced flooding. Foul odors rose from drainage pipes meant for storm-water treatment, and residents often covered them with linoleum pads. Roads in the area also became extremely slippery when it rained.

\subsubsection{Local Physical Conditions}

The next phase of the study examined the community's physical conditions to better understand the community and collect data on its shared problems. Part of the field investigation examined the physical conditions of traditional markets, public parking spaces, and roads within the community. Poor roads and inadequate parking were found particularly around the area of the market merchants, which is the heart of the community's culture. Figure 3 displays the examined location.

We divided local physical conditions into nine categories, as shown in Figure 3. They included in-town roads (A), the surrounding area of Youngsan University (B), a commercial district and areas surrounding the main road $(\mathrm{C})$, outer roads $(\mathrm{D})$, buildings $(\mathrm{E})$, living conditions along the streets $(\mathrm{F})$, Bansong's side-street markets $(\mathrm{G})$, drainage pipes $(\mathrm{H})$, and green spaces and rest areas (I). One field investigation goal was to gather sufficient information to determine appropriate topics for discussion during resident interviews. We therefore present the information gathered from A1 to I5 to gauge the community's problems. 


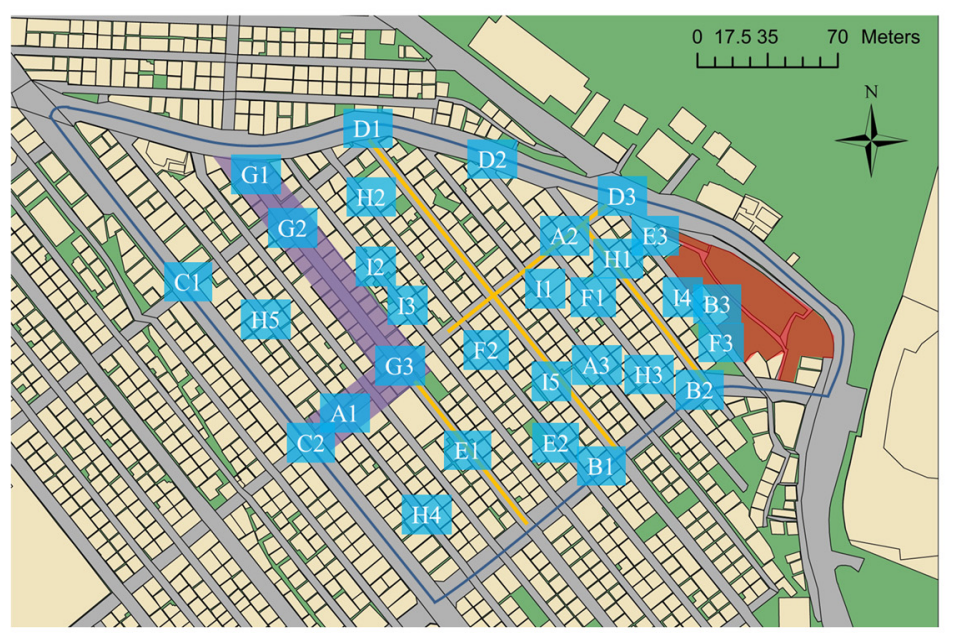

- study area boundary

- roads in the village where vehicle

traditional local market transport is possible
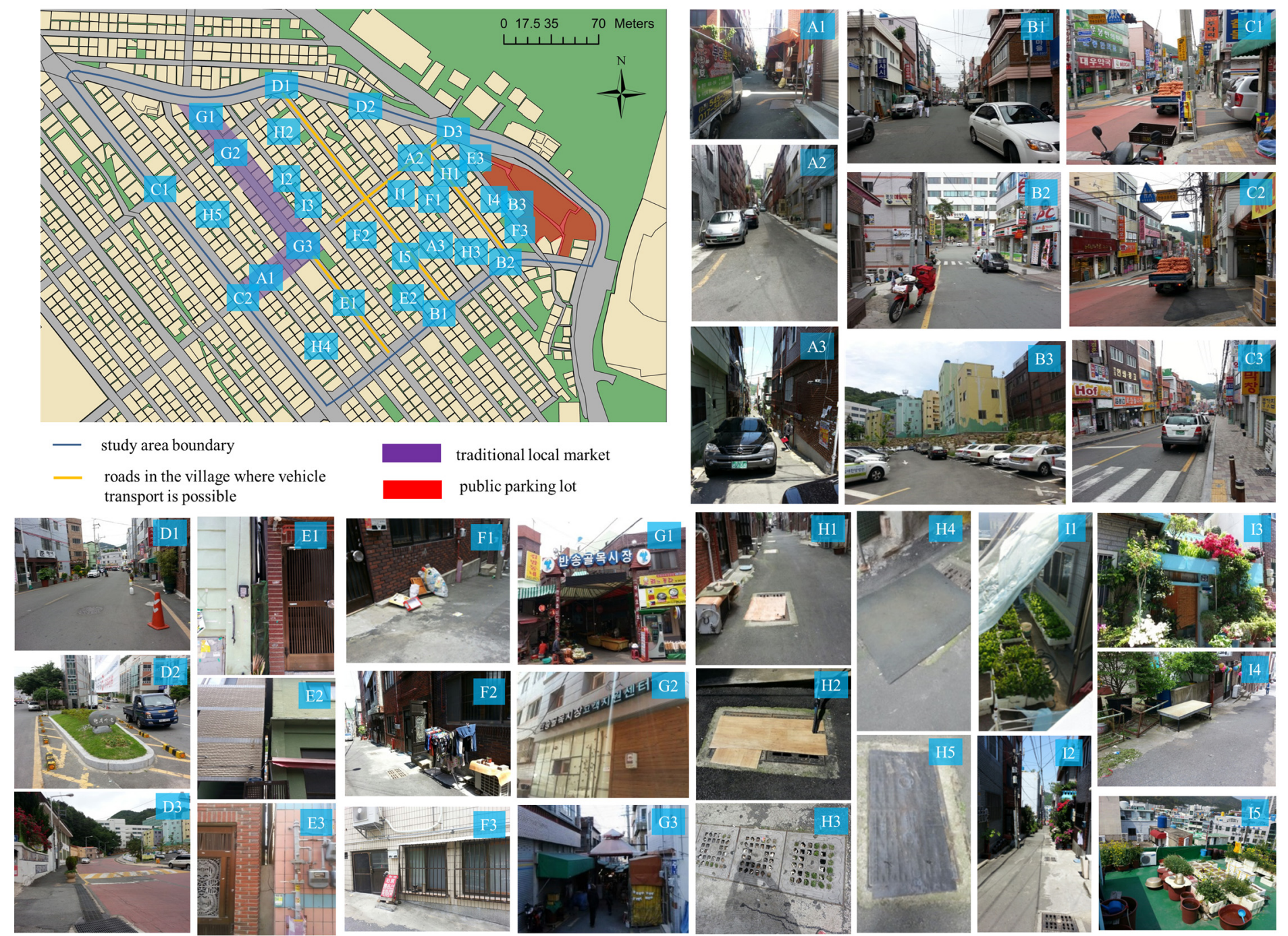

Figure 3. Field investigation of the local physical conditions. 


\subsection{Building Consensus with Locals.}

\subsubsection{Sharing Local Problems}

From May 15-17, 2014, we conducted in-depth interviews with 23 local residents using the items examined in the first step, in order to properly conduct local problem sharing. First, the planner presented a specific situation showing the community's problems, asked for local residents' opinions, and then held a discussion. We presented 31 local physical conditions (deduced from A1-I5) as specific problems. In conjunction, the planner added explanations about these conditions, including information related to climate change and disasters, history and culture, and residents' behaviors and characteristics. Table 2 displays the results of the in-depth interviews.

Table 2. Problems discussed during in-depth interviews.

\section{Type of Community Problem Problem Discussed during in-Depth Interviews}

(1) It is difficult to manage fires and other emergencies due to the road's narrow passageway, making it hard for vehicles to pass; (2) High slopes, illegal parking, and motorcycle pathways impede safe passage, particularly for children and the elderly; (3) Disabled and elderly individuals lack access to transportation as well as parking in or near buildings; (4) It is difficult to pass through narrow

(A) Transit and passage difficulties alleys because of the air-conditioning units, and these units create added danger in relation to in-town roads in the summer due to the heat they expel; (5) Travel is impeded by summer rain, winter snow, and ice; (6) Small spacing between buildings creates an absence of sunlight; (7) There are privacy concerns related to installing security cameras (privacy may be infringed upon because the buildings are so close together), which results in an increased risk of crime when security cameras cannot be installed; (8) The lack of trees and parks in alleys means there are no rest areas.

(1) Youngsan University students primarily utilize the commercial area located in the northern area $(\mathrm{B} 1, \mathrm{~B} 2)$ of the community, and daytime transit is crowded; (2) Facilities like convenience stores, coffee shops, PC rooms, and bars are used

(B) Parking problems and travel difficulties primarily by students, not local residents. Local residents utilize neighborhood parks and sports parks as transportation routes, but human, car, and motorcycle transit are entangled together and are dangerous; (3) Public parking lots are wide, but parking is still lacking when compared to the community's population; (4) The proximity of preschools and kindergartens to public parking lots creates inherent dangers.

(1) This area is densely populated with hospitals, pharmacies, restaurants, and shops, and is the center of its residents' lives. The town bus (Haeundae no. 11) is in service here; (2) Illegal parking makes navigating the roads difficult, and, similarly, travel on foot is impeded on the newly installed footpaths because people leave items outside shops and park their motorcycles there; (3) Local

(C) Traffic problems, conflict over footpath installation, pedestrian accidents, and safety issues in the business district and on the main road residents held differing opinions about the footpath installation. Residents were in favor, but shop owners opposed it due to problems with store accessibility; (4) This area has the most pedestrian accidents because the pavement becomes slippery during rainfall (construction did not take into consideration the hilly geography); (5) Streetlight is lacking, resulting in safety issues when walking at night; (6) Shops have no parking lots, and illegal parking at night is rampant.

(1) Walking is dangerous due to the Youngsan University shuttle buses and preschool buses that travel along the road from the subway station and bus stop to the university; (2) The preschool, kindergarten, and residential center is

(D) Issues regarding difficulties with safe transit, danger of car accidents, and community work in the community's outer roads located on the other side of the community, making safe transit difficult; (3) This is an area that needs footpaths, which have yet to be installed despite requests from residents; (4) Traffic accidents occur because of road structure problems;

(5) A resident rest area is partially installed as part of the government supported work (Happiness Village) but is located in an inaccessible area; (6) The area has a handicraft workshop, cooperative association, and town library, which are all part of the Happiness Village work supported by the government (These were not connected to existing merchants). 
Table 2. Cont.

\begin{tabular}{|c|c|}
\hline Type of Community Problem & Problem Discussed during in-Depth Interviews \\
\hline $\begin{array}{l}\text { (E) Humidity problems, fire } \\
\text { dangers, and problems from } \\
\text { narrow spacing between buildings } \\
\text { in the community }\end{array}$ & $\begin{array}{l}\text { (1) Wind does not easily pass through the narrow spaces between buildings and } \\
\text { results in humidity; (2) There are instances of windows facing each other, noise } \\
\text { problems, and fire dangers; (3) Internet and electric cables between buildings } \\
\text { are tangled together, and some homes have storm drains that empty from the } \\
\text { roof; (4) Buildings can become habitats for harmful insects and other pests; (5) } \\
\text { There are no routes between buildings, cutting off movement in the community. }\end{array}$ \\
\hline $\begin{array}{l}\text { (F) Hygiene, foul smells, and } \\
\text { harmful insects in relation to living } \\
\text { conditions along the road }\end{array}$ & $\begin{array}{l}\text { (1) There is a lack of household space (no balconies), so laundry is usually dried } \\
\text { in an alley in front of the house due to humidity; (2) Narrow spaces between } \\
\text { buildings and the direction of windows results in a lack of sunlight entering the } \\
\text { houses; (3) Garbage collects at an intersecting point between the fronts of } \\
\text { houses and the alley, resulting in hygiene issues; (4) The population density of } \\
\text { the area makes for an abundance of waste; (5) Since first floor households are } \\
\text { located on a slope and some of their doors and windows are lower than the } \\
\text { road, rainwater sometimes enters these homes. }\end{array}$ \\
\hline $\begin{array}{l}\text { (G) Problems with revitalizing } \\
\text { markets, government assistance, } \\
\text { and safety issues in relation to the } \\
\text { area around Bansong's side-street } \\
\text { markets }\end{array}$ & $\begin{array}{l}\text { (1) Alleys and side streets are filled with small markets. Local residents } \\
\text { primarily utilize this space. Most merchants are community residents. Recently, } \\
\text { business has declined due to economic stagnation; ( } 2 \text { ) Customer support } \\
\text { centers were created by the government to assist traditional markets, but there } \\
\text { are high maintenance fees to manage; ( } 3 \text { ) The government's community } \\
\text { support programs, such as the Silver Café, handicraft workshops, and urban } \\
\text { farm work, have not become popular; (4) Improvement of traditional markets } \\
\text { has been difficult due to disagreements about the burden of costs; (5) It is } \\
\text { impossible for emergency vehicles to pass through side-street markets, making } \\
\text { these areas vulnerable to fire, heavy rain, and heatwaves. }\end{array}$ \\
\hline $\begin{array}{l}\text { (H) Foul odors, transportation } \\
\text { difficulties, and humidity } \\
\text { problems in relation to community } \\
\text { drainage pipes }\end{array}$ & $\begin{array}{l}\text { (1) When it rains, stormwater from the mountains and town flow directly into } \\
\text { streams; (2) Stormwater inlets were installed every ten meters after the typhoon, } \\
\text { but sewage and waste mix together and create foul odors; (3) Wastewater and } \\
\text { stormwater drains are not separated, resulting in foul odors all year; (4) The } \\
\text { majority of rainwater drains are covered with linoleum and rubber to cope with } \\
\text { the foul odors and harmful pests; (5) Humidity is also a major problem due to } \\
\text { water that flows from the mountains }\end{array}$ \\
\hline $\begin{array}{l}\text { (I) Local resident rest areas, places } \\
\text { to relax, and the lack of green } \\
\text { space in relation to community } \\
\text { green spaces and rest areas }\end{array}$ & $\begin{array}{l}\text { (1) There are virtually no green spaces in the community. There is a large } \\
\text { mountain nearby but usage rates are low; (2) There are no rest areas in the } \\
\text { community; (3) Trees and flowers exist around some areas with detached house } \\
\text { units, and, in other areas, local residents have built rest areas; (4) Community } \\
\text { vegetable gardens exist on some rooftops as part of an urban farm support } \\
\text { effort; (5) Local residents would like to have vegetable gardens and green } \\
\text { spaces in the community, but it is difficult to secure space for these. }\end{array}$ \\
\hline
\end{tabular}

\subsubsection{Identifying Local Needs}

In order to confirm the determined problems and establish the local needs to develop the community plan, we invited stakeholders to participate in community workshops. The eight stakeholders, including market merchant representatives, community leaders, women's association representatives, village community work facilitators, and area activists, participated in local resident workshops beginning May 30, 2014.

First, the planners used outputs, which included a community map, local physical conditions, and local problems to categorize the local, physical conditions by type. We then discussed these conditions with the stakeholders. From there, the community stakeholders marked areas on the map where problems needed to be resolved based on interactive discussions with the planners. Figure 4 displays these marked areas. 


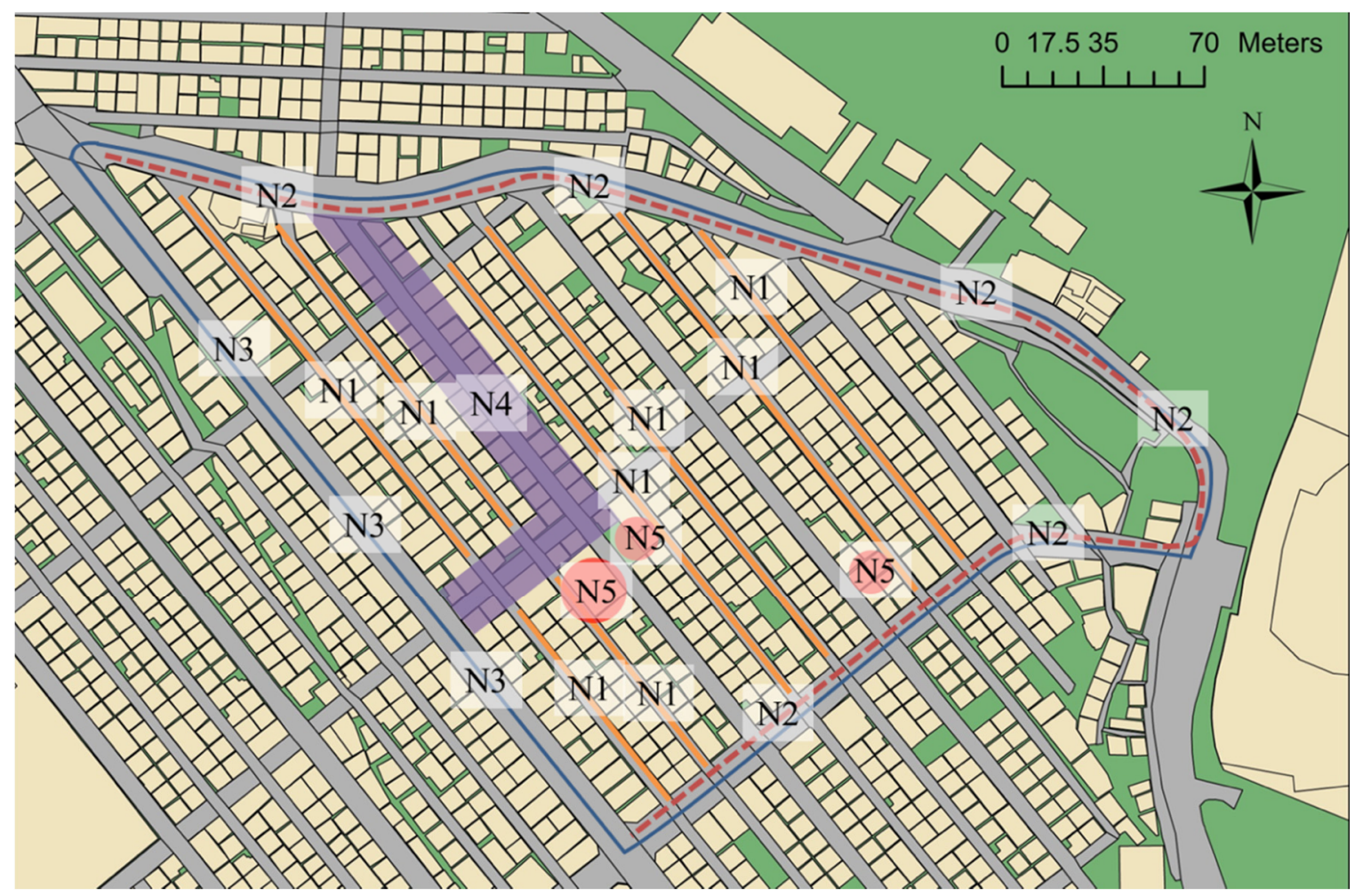

Figure 4. Community local needs mapping.

We organized the local needs discussed in the workshop into five types: N1-N5. N1 is related to village road safety. The condition of the village roads, marked N1, make safe transit difficult. Although other problems exist, like foul odors during heatwaves and heavy rains, the community made safe transit a priority. The community's outer roads, marked N2, are structured such that safe transit for the elderly and children is difficult. There is a need to improve road structures and create walkways and safety facilities on both sides of the road. N3 has the highest frequency of accidents during rain, which calls for replacing the surface of the road with a material that is not slippery. The workshop also presented the need to secure streetlights and security camera equipment sufficient for the main road. N4 is an area with street-side markets, and the markets need internal maintenance. This includes maintenance of the areas where items are sold as well as painting the area. N5 is a deserted area, and its needs involve better utilization of space, including transforming the area's insufficient parking spaces, rest areas, and green spaces.

\subsubsection{Mining Local Knowledge}

In the previous steps, it was important to know what the planner would use as local knowledge in community planning, specifically with respect to residents' opinions about community problems and the needs of local stakeholders. It is virtually impossible to transform a community through climate change adaptation measures alone. Community members and stakeholders are often more interested in their community's growth and problem-solving than they are in climate change adaptation. Therefore, planners need to be able to simultaneously apply and deduce adaptation measures by using mainstream objectives and local knowledge. In total, four keyword groups appeared in the Bansong Pilbongoreum community. The results are shown in Figure 5. 


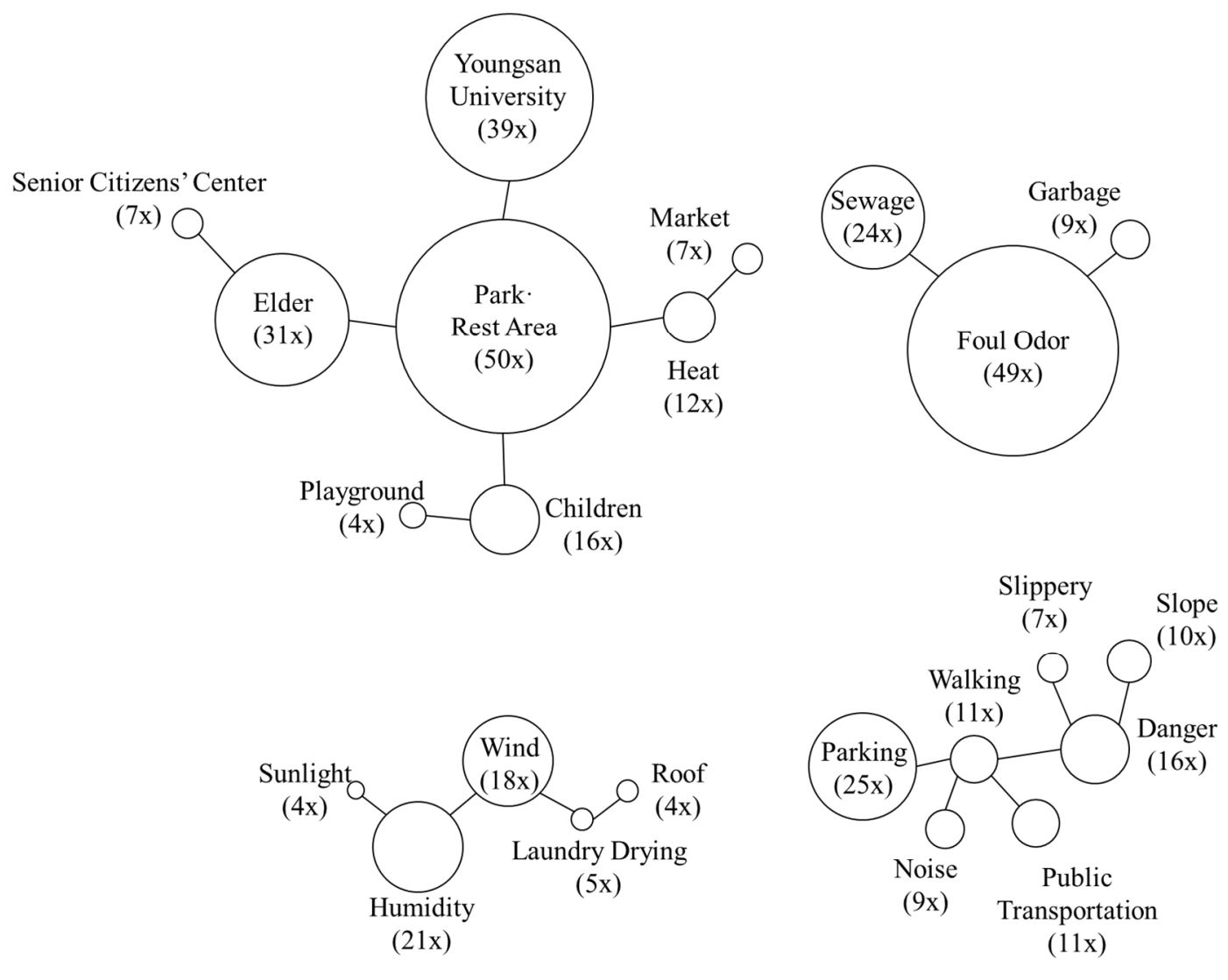

Figure 5. Local knowledge mining results.

The four keywords categories of Bansong Pilbongoreum local knowledge included parks-rest areas, foul odors, humidity, and parking. A group related to parks-rest areas was independently connected with demographic characteristics of children and the elderly, Youngsan University's spatial characteristics, and the weather characteristic of heat. This means that, instead of connecting parks and rest areas into one issue and resolving the problem during planning, one must consider planning measures appropriate for each characteristic and apply them in a manner that holistically addresses the community's characteristics. The fact that parks-rest areas are connected with heat shows that adaptation measures for heatwaves can be jointly handled during planning.

The group related to foul odors clearly identified the targets that needed to be handled during planning - sewage and garbage. The aspect related to sewage can become a planning objective for heavy rain adaptation measures and, through this, lowland flooding can also be addressed. It is also clear that the garbage problem is a planning objective that needs to be resolved in conjunction with foul odor problems.

The group related to humidity connected a variety of keywords together. When considering the investigation results of local conditions, humidity accompanies issues in which sunlight does not enter the house and wind cannot pass through. This becomes a problem when trying to dry laundry outside. A related phenomenon is the difficulty in implementing crime prevention measures when laundry must be dried on one's roof. This means that planners must consider humidity as a weather factor and prepare measures related to health vulnerabilities in the elderly and children when creating adaptation measures.

Lastly, the group related to parking reveals the complex problems that arise from traffic and transit in the target area. Parking problems in the community are connected to the dangers that arise when individuals walk, which is related to the community's hilly topography and the tendency of its roadways and walkways to be slippery. There are also public transportation issues and noise problems that are linked to walking conditions. This type of local knowledge dictates that, when planners seek 
to ameliorate parking and walking dangers, an objective must be established that creates mutually connected complex solutions instead of simple, independent ones. Also, planners must take into consideration climate change adaptation and complex functions in spaces to resolve problems like parking and walking dangers.

\section{Discussion}

This study proposed a process of consensus-building through participation as a preliminary process in creating a climate change adaptation plan for the community. In dealing with the uncertain future of climate change, planners face various barriers with residents, such as a lack of understanding and indifference to climate change, conservatism toward change, and a range of interests and conflicts that are likely to persist for future residents. We deduced the following implications and value for planners when introducing consensus-building as an early step in the planning process.

First, one must be able to connect with problems faced by local residents in order to consider climate change adaptation in the community. Handling climate change adaptation within a community is difficult $[88,89]$. The community's residents may not only be uninterested in climate change, but it is also possible that they do not understand its associated language and phenomena [63]. In their process, planners come across a wide range of opinions, from skepticism to climate change to those who believe it requires an active response. Many people may also feel that climate change adaptation is a problem that is quite distant from their real lives. Even if there is a need to emphasize the problems of climate change adaptation and mainstream policy measures in communities, there is no need for planners to directly use climate change as a topic of discussion with local residents. Planners must deduce the present problems faced by the community and create a strategy to connect those problems to climate change. Planners, through communication with local residents, can present climate change adaptation to resolve community problems.

Second, in order to connect local knowledge to community-based adaptation planning, planners must understand the community's situation and must initiate communication with local residents in the early stages of decision making, in which the planner establishes the objectives that need to be resolved. Many planners fail to share a mutual understanding with the local residents regarding the community's problems and fail to include local residents in the problem recognition phase $[90,91]$. This causes local residents to have an unclear understanding of the problem and results in them becoming disinterested in the determined problems. Due to the planners' status as community outsiders, it is difficult for them to perfectly grasp local circumstances, and it is possible that they lack common experiences with the local residents [16-19]. Local knowledge is built from the experiences of local residents, and it can, therefore, be useful to a planner in recognizing problems and deducing the community's needs. Understanding local problems in the early stages by communicating with local residents becomes the foundation for building the trust shared between planners and residents.

Third, planners must listen to as many different opinions from local residents as possible in order to reflect the interest of local residents. In the participation process, local residents possess a diverse spectrum of opinions in regard to their interests and needs. To avoid the possibility that some residents' opinions may be ignored, the planner must provide opportunities to a variety of residents to reflect a diversity of opinions from a balanced perspective. In the early steps, planners must be willing to allot sufficient time, energy, and money to listening to opinions from as many local residents as possible in a variety of locations. This process prevents opinion bias problems that follow power vacuums or power relations within communities, and this process is beneficial to reflecting balanced views.

An epistemological understanding of local residents' knowledge is needed to incorporate appropriate local knowledge into planning. The fact that local knowledge is difficult to directly implement in planning is an inevitable result of the different processes planners use to attain specialized knowledge. Planners need to understand the methods that local residents claim and discuss. They also need to recognize these differences, continuously review the question and confirmation process, and increase mutual understanding in order to reflect local knowledge. 
Content analysis can be useful for structuring the planner's efforts [63]. Although many studies on community planning and community-based adaptation include important discussions on the process of participation, it is unclear how the various opinions drawn during a participatory process should be reflected in the planning process [92,93]. The content analysis used in this study is one way of understanding local knowledge related to the problems facing the community from the perspective of the majority opinion. This has the advantage of directly linking the goals of the plan with the local problems, based on the general opinions of community residents.

Finally, in the early steps of planning, planners must be able to properly perform the role of facilitators to elicit local knowledge through open communication with local residents. Planners must prepare a variety of tools to represent residents' opinions, which requires them to understand the local culture and use it to create a space where they can discuss their opinions. When local residents express an opinion and engage in communication, planners are required to adjust and modify their planning objectives and techniques accordingly. In this process, it is important for the planner to access those parts of the community that are commons. Communities have a variety of commons, and planners should engage with locals that directly target the space as commons for the community. Planners need to communicate with local residents with local as commons and also need to act as facilitators to enable more people to comment on local issues.

\section{Conclusions}

Using Korea's Bansong Pilbongoreum community as a research subject, we recommended a series of processes that planners can use to gather local knowledge and build a consensus while developing community climate change adaptations. In the first step we identified the local conditions, including local history and culture, local climate and disasters, local residents' behavior and characteristics, and local physical conditions, through field investigation. In the next step, to build consensus with locals, we shared the local problems through in-depth interviews and identified local needs through community workshops with stakeholders. In the final step, we used content analysis to analyze data gathered from the in-depth interviews and community workshops, and then we identified the local knowledge for planning objectives. We focused on recognizing problems that may be overlooked in the early stages of the planning process. We examined the circumstances surrounding various problems in order to elicit local knowledge through communications with local residents and deduced local problems and needs by examining physical conditions. In the process of deducing problems and approaches that must be reconciled for the community, planners and local residents can engage in consensus-building and arrive at planning objectives by mining local knowledge.

This study is meaningful in that suggested early steps that can be used in the planning stage of community-based adaptation by identifying local needs. In particular, we presented the process of consensus-building in three stages, in which the planner grasps the local knowledge of the community and builds rapport with the residents. This will play a role in establishing community-based adaptation planning that integrates policy measures with the local needs and climate change adaptation of communities.

However, this study has some limitations. First, there was a limitation in identifying the community's characteristics since the result of deriving local knowledge based on local needs should be reinforced by statistically supporting the phenomena with data. In this study, there was no statistical data available at the community level, so it was not possible to apply it to the research. Based on the early steps of planning presented in this study, future research should identify statistical data to actually establish a community-based adaptation plan. In addition, if statistics are not available, local knowledge should be supported through data collection at the next planning stage.

This study also focused on deriving planning objectives based on the early steps of planning, which limits the role played by decision making in overall planning. Research into how effective the introduction of the early steps of participation and consensus-building is in leading to effective decision making throughout the planning process is needed. Future research on measuring the effectiveness of 
the process will further allow us to compare it with existing top-down planning processes and suggest more advanced forms for each process.

Author Contributions: D.K. designed the research and drafted the manuscript. J.E.K. guided this work and provided extensive revision during the study. Both authors wrote, read, and approved the final manuscript. All authors have read and agreed to the published version of the manuscript.

Funding: This study was partially supported by the National Research Foundation of Korea (NRF) grant funded by the Korean government (No. NRF-2017R1A2B4008057) and was partially supported by Korea Ministry of Environment (MOE) as the Graduate School specialized in Climate Change.

Conflicts of Interest: The authors declare no conflict of interest.

\section{References}

1. Van Tatenhove, J.P.M.; Leroy, P. Environment and participation in a context of political Modernization. Environ. Values 2003, 12, 155-174. [CrossRef]

2. Hickey, S.; Mohan, G. Participation: From Tyranny to Transformation? Exploring New Approaches to Participation in Development; Zed Books: London, UK, 2005.

3. Van Herzele, A.; Van Woerkum, C.M.J. Local knowledge in visually mediated practice. J. Plan. Educ. Res. 2008, 27, 444-455. [CrossRef]

4. Berkes, F. Rethinking community-based conservation. Conserv. Biol. 2004, 18, 621-630. [CrossRef]

5. Innes, J.E.; Booher, D.E. Planning with Complexity: An introduction to Collaborative Rationality for Public Policy; Routledge: London, UK, 2010.

6. Kapoor, I. Towards participatory environmental management? J. Environ. Manag. 2001, 63, 269-279. [CrossRef] [PubMed]

7. Petts, J.; Brooks, C. Expert conceptualizations of the role of lay knowledge in environmental decision-making: Challenges for deliberative democracy. Environ. Plan. A 2006, 38, 1045-1059. [CrossRef]

8. Fazey, I.; Fazey, J.A.; Salisbury, J.G.; Lindenmayer, D.B.; Dovers, S. The nature and role of experiential knowledge for environmental conservation. Environmental Conservation 2006, 33, 1-10. [CrossRef]

9. Innes, J.E. Information in communicative planning. J. Am. Plan. Assoc. 1998, 64, 52-64. [CrossRef]

10. Johnson, M.S. Public participation and perceptions of watershed modelling. Society and Natural Resources 2009, 22, 79-87. [CrossRef]

11. Dietz, T.; Ostrom, E.; Stern, P.C. The struggle to govern the commons. Science 2003, 302, 1907-1912. [CrossRef] [PubMed]

12. Bruun, O.; Olwig, M.F. Is local community the answer? The role of 'local knowledge' and 'community' for disaster prevention and climate adaptation in central Vietnam. Asian J. Soc. Sci. 2015, 43, 811-836. [CrossRef]

13. Brown, K.; Westaway, E. Agency, capacity, and resilience to environmental change: Lesson from human development, well-being and disasters. Annu. Rev. Environ. Resour. 2011, 36, 321-342. [CrossRef]

14. Hawkins, E.; Sutton, R. The potential to narrow uncertainty in regional climate predictions. Bull. Am. Meteorol. Soc. 2005, 90, 1095-1107. [CrossRef]

15. Fernandez, M.; Hamilton, H.; Kueppers, L.M. Characterizing uncertainty in species distribution models derived from interpolated weather station data. Ecosphere 2013, 4, 1-17. [CrossRef]

16. Huntington, H.P. The local perspective. Nature 2011, 478, 182-183. [CrossRef] [PubMed]

17. Couzin, J. Opening doors to native knowledge. Science 2007, 315, 1518-1519. [CrossRef]

18. Marin, A.; Berkes, F. Local people's accounts of climate change: To what extent are they influenced by the media? Wires Clim. Chang. 2013, 4, 1-8. [CrossRef]

19. Klein, J.A.; Hopping, K.A.; Yeh, E.T.; Nyima, Y.; Boone, R.B.; Galvin, K.A. Unexpected climate impacts on the Tibetan Plateau: Local and scientific knowledge in findings of delayed summer. Glob. Environ. Chang. 2014, 24, 141-152. [CrossRef]

20. Corburn, J. Bringing local knowledge into environmental decision making: Improving urban planning for communities at risk. J. Plan. Educ. Res. 2003, 22, 420-433. [CrossRef]

21. Reyes-Garcia, V.; Fernández-Llamazares, Á.; Guèze, M.; Mallo Garcés, A.; Vila-Gómez, M.; Vilaseca, M. Local indicators of climate change: The potential contribution of local knowledge to climate research. Wires Clim. Chang. 2016, 7, 109-124. [CrossRef] [PubMed] 
22. Lindblom, C.E.; Cohen, D.K. Usable Knowledge: Social Science and Social Problem Solving; Yale University Press: New Haven, CT, USA, 1979.

23. Geertz, C. Local Knowledge; Basic Books: New York, NY, USA, 1983.

24. Fischer, F. Citizens, Experts, and the Environment: the Politics of Local Knowledge; Duke University Press: London, UK, 2000.

25. Ballard, H.L.; Fernandez-Gimenez, M.E.; Sturtevant, V.E. Integration of local ecological knowledge and conventional science: A study of seven community-based forestry organizations in the USA. Knowl. Soc. 2008, 13, 37. [CrossRef]

26. Puppim de Oliveira, J.A.; Fra Paleo, U. Lost in participation: How local knowledge was overlooked in land use planning and risk governance in Tōhoku, Japan. Land Use Policy 2016, 52, 543-551. [CrossRef]

27. Lundvall, B.A.; Johnson, B. The learning economy. J. Ind. Stud. 1994, 1, 23-42. [CrossRef]

28. Rhoads, B.L.; Wilson, D.; Urban, M.; Herricks, E.E. Interaction between scientists and nonscientists in community-based water management: Emergence of the concept of stream naturalization. Environ. Manag. 1999, 24, 297-308. [CrossRef] [PubMed]

29. Krimsky, S. Epistemic considerations on the values of folk-wisdom in science and technology. Policy Stud. Rev. 1984, 3, 246-264. [CrossRef]

30. Sandercock, L. Out of closet: The importance of stories and storytelling in planning practice. Plan. Theory Pract. 2003, 4, 11-28. [CrossRef]

31. Blowers, A.; Boersma, J.; Martin, A. Experts, decision making and deliberative democracy. Environ. Sci. 2005, 2, 1-3. [CrossRef]

32. Arnstein, A. A ladder of citizenship participation. J. Am. Inst. Plan. 1969, 26, 216-233. [CrossRef]

33. Biggs, S. Resource-Poor Farmer Participation in Research: A Synthesis of Experiences from Nine National Agricultural Research Systems-OFCOR Comparative Study Paper, No. 3; International Service for National Agricultural Research: Hague, The Netherlands, 1989.

34. Rowe, G.; Frewer, L. Public participation methods: A framework for evaluation in science. Technol. Hum. Values 2000, 25, 3-29. [CrossRef]

35. Lawrence, A. No personal motive? Volunteers, biodiversity, and the false dichotomies of participation. Ethics Place Environ. 2006, 9, 279-298. [CrossRef]

36. Martin, A.; Sherington, J. Participatory research methods-Implementation, effectiveness and institutional context. Agric. Syst. 1997, 55, 195-216. [CrossRef]

37. Reed, M.S. Participatory technology development for agroforestry extension: An innovation-decision approach. Afr. J. Agric. Res. 2007, 2, 334-341.

38. Dougill, A.J.; Fraser, E.D.G.; Holden, J.; Humacek, J.; Prell, C.; Reed, M.S.; Stringer, L.C. Learning from doing participatory rural research: Lessons from the Peak District National Park. J. Agric. Econ. 2006, 57, 259-275. [CrossRef]

39. Newig, J. Does public participation in environmental decisions lead to improved environmental quality? Towards an analytical framework. Commun. Coop. Particip. 2007, 1, 51-71.

40. Koontz, T.M.; Thomas, C.W. What do we know and need to know about the environmental outcomes of collaborative management? Public Adm. Rev. 2006, 66, 111-121. [CrossRef]

41. Richards, C.; Blackstock, K.L.; Carter, C.E. Practical Approaches to Participation SERG Policy Brief No. 1; Macaulay Land Use Institute: Aberdeen, UK, 2004.

42. Murdoch, J.; Clark, J. Sustainable knowledge. Geoforum 1994, 25, 115-132. [CrossRef]

43. Giordano, R.; Liersch, S.; Vurro, M.; Hirsch, D. Integrating local and technical knowledge to support soil salinity monitoring in the Amudarya River Basin. J. Environ. Manag. 2010, 91, 1718-1729. [CrossRef] [PubMed]

44. Berkes, F. Cross-scale institutional linkages: Perspectives from the bottom up. In The Drama of the Commons; Ostrom, E., Dietz, T., Dolsak, N., Stern, P.C., Stonich, S., Eds.; National Academy Press: Washington, DC, USA, 2002; pp. 293-321.

45. Burby, R.J.; May, P.J. Command or cooperate? Rethinking traditional central governments' hazard mitigation policies. In Building Safer Communities. Risk Governance, Spatial Planning and Responses to Natural Hazards; Fra. Paleo, U., Ed.; IOS Press: Amsterdam, The Netherlands, 2009; pp. 21-23.

46. Flyvbjerg, B. Making Social Science Matter: Why Social Inquiry Fails and How It Can Succeed Again; Cambridge University Press: New York, NY, USA, 2001. 
47. Healey, P. Collaborative planning in perspective. Plan. Theory 2003, 2, 101-123. [CrossRef]

48. Vedwan, N.; Ahmad, S.; Miralles-Wilhelm, F.; Broad, K.; Letson, D.; Podesta, G. Institutional evolution in Lake Okeechobee management in Florida: Characteristics, impacts, and limitations. Water Resour. Manag. 2008, 22, 699-718. [CrossRef]

49. Fischer, A.; Young, J.C. Understanding mental constructs of biodiversity: Implications for biodiversity management and conservation. Biol. Conserv. 2007, 136, 271-282. [CrossRef]

50. Van Herzele, A. Local knowledge in action: Valuing nonprofessional reasoning in the planning process. J. Plan. Educ. Res. 2004, 24, 197-212. [CrossRef]

51. Campbell, H.; Marshall, R. Public involvement and planning: Looking beyond the one to the many. Int. Plan. Stud. 2000, 5, 321-344. [CrossRef]

52. Healey, P. Collaborative Planning: Shaping Places in Fragmented Societies; Macmillan: London, UK, 1997.

53. Foster, J. Planning in the Face of Power; University of California Press: Berkeley, CA, USA, 1989.

54. Schön, D.; Rein, M. Frame Reflection: Toward the Resolution of Intractable Policy Controversies; Basic Books: New York, NY, USA, 1994.

55. Healey, P.; Hillier, J. Communicative micropolitics: A story of claims and discourses. Int. Plan. Stud. 1996, 1, 165-184. [CrossRef]

56. Innes, J.E.; Booher, D.E. Consensus building as role playing and bricolage: Toward a theory of collaborative planning. J. Am. Plan. Assoc. 1999, 65, 9-26. [CrossRef]

57. Reed, M.S.; Fraser, E.D.G.; Dougill, A.J. An adaptive learning process for developing and applying sustainability indicators with local communities. Ecol. Econ. 2006, 59, 406-418. [CrossRef]

58. Al-Kodmany, K. Visualization tools and methods in community planning: From freehand sketches to virtual reality. J. Plan. Lit. 2002, 17, 189-211. [CrossRef]

59. Wates, N. The Community Planning Handbook; Earthscan: London, UK, 2000.

60. Kingston, R.; Carver, S.; Evans, A.; Turton, T. Web-based public participation geographical information systems: An aid to local environmental decision-making. Comput. Environ. Urban Syst. 2000, 24, 109-125. [CrossRef]

61. Campos, I.; Vizinho, A.; Coelho, C.; Alves, F.; Truninger, M.; Pereira, C.; Santos, F.D.; Lopes, G.P. Participation, scenarios and pathways in long-term planning for climate change adaptation. Plan. Theory Pract. 2016, 17, 537-556. [CrossRef]

62. Adger, W.N.; Kelly, P.M. Social vulnerability to climate change and the architecture of entitlements. Mitig. Adapt. Strateg. Glob. Chang. 1999, 4, 253-266. [CrossRef]

63. Measham, T.G.; Preston, B.L.; Smith, T.F.; Brooke, C.; Gorddard, R.; Withycombe, G.; Morris, C. Adapting to climate change through local municipal planning: Barriers and challenges. Mitig. Adapt. Strateg. Glob. Chang. 2011, 16, 889-909. [CrossRef]

64. Kim, D.; Kang, J.E. Integrating climate change adaptation into community planning using a participatory process: The case of Saebat Maeul community in Busan, Korea. Environ. Plan. B: Urban Anal. City Sci. 2018, 45, 669-690. [CrossRef]

65. Mitlin, D.; Satterthwaite, D. Urban Poverty in the Global South: Scale and Nature; Routledge: New York, NY, USA, 2013.

66. O’Brien, K.; Eriksen, S.; Sygna, L.; Naess, L.O. Questioning complacency: Climate change impacts, vulnerability, and adaptation in Norway. AMBIO 2006, 35, 50-56. [CrossRef]

67. Tribbia, J.; Moser, S.C. More than information: What coastal managers need to plan for climate change. Environ. Sci. Policy 2008, 11, 315-328. [CrossRef]

68. Vigar, G. Towards an integrated spatial planning? Eur. Plan. Stud. 2013, 17, 1571-1590. [CrossRef]

69. Kiunsi, R. The constraints on climate change adaptation in a city with a large development deficit: The case of Dar es Salaam. Environ. Urban. 2009, 25, 321-337. [CrossRef]

70. Reid, H.; Alam, M.; Berger, R.; Cannon, T.; Huq, S.; Milligan, A. Community-based adaptation to climate change: An overview. Participatory Learning and Action 2009, 60, 11-33.

71. Burch, S. Transforming barriers into enablers of action on climate change: Insights from three municipal case studies in British Columbia, Canada. Glob. Environ. Chang. 2010, 20, 287-297. [CrossRef]

72. Roberts, D. Prioritizing climate change adaptation and local level resilience in Durban, South Africa. Environ. Urban. 2010, 22, 397-413. [CrossRef] 
73. Livengood, A.; Kunte, K. Enabling participatory planning with GIS: A case study of settlement mapping in Cuttack, India. Environ. Urban. 2012, 24, 77-97. [CrossRef]

74. Laurian, L. Trust in planning: Theoretical and practical considerations for participatory and deliberative planning. Plan. Theory Pract. 2009, 10, 369-391. [CrossRef]

75. Kim, D.; Lee, S.; Lee, M.J.; Seo, H.-J. Spatial Planning Method and Applications for Climate Change Adaptation I.; Korea Environment Institute: Sejong, Korea, 2014.

76. Kim, D.; Lee, J.-H.; Lee, M.J.; Seo, H.-J.; Jung, J.C.; Kang, J.E.; Kim, J.S. Spatial Planning Method and Applications for Climate Change Adaptation II.; Korea Environment Institute: Sejong, Korea, 2015.

77. Yoo, D.C.; Park, J.H. Strategy for developing Rothman's community locality. J. Korean Policy Stud. 2015, 15, 47-69.

78. Korea Broadcasting System KBS. Returned to the Village: 72 Hours with the People of Busan Bansong-Dong. Available online: http://www.kbs.co.kr/2tv/sisa/3days/view/vod/index,1,1_list003,24.html (accessed on 29 October 2019).

79. Meditory. Documentary-I Live in Bansong. Available online: http://www.meditory.net/archives/project/84/ (accessed on 29 October 2019).

80. Kookje Daily News. Worker Heat Diseases at Construction Sites Bansong. Available online: http://www.kookje.co.kr/news2011/asp/newsbody.asp?code=0300\&key=20100806.22001220154 (accessed on 29 October 2019).

81. Kwon, Y.M.; Cho, S.K. A study on the characteristics of residential district with the process of urban growth in Pusan. J. Archit. Inst. Korea Plan. Des. 2000, 16, 109-118.

82. Kim, S.T.; Kim, K.J.; Kwon, Y.S. Reading the Busan hillside residential landscape as the Korean War refugee's settlement. J. Urban Des. Inst. Korea Urban Des. 2016, 17, 79-98.

83. Lee, Y.A. Exploring key facts of residents' participation for local capacity building. J. Korean Assoc. Reg. Geogr. 2009, 15, 261-272. [CrossRef]

84. Korea Meteorological Administration and Busan Regional Office of Meteorology. A detailed Analytic Report on Climate Change in Haeundae-Gu of the Busan Metropolitan Area; Korea Meteorological Administration: Seoul, Korea, 2015.

85. Busan Daily News. Area Flooding Due to Stream Overflow Bansong. Available online: http://www.busan. com/view/busan/view.php?code=20060712000050 (accessed on 29 October 2019).

86. Ulsan Daily News. Bansong Area Flooding Due to Hourly Flooding of 130mm of Torrential Rain. Available online: http://www.iusm.co.kr/news/articleView.html?idxno=473714 (accessed on 29 October 2019).

87. KNN. Health Risks for Elderly in Dilapidated Dwellings. Available online: http://www.knn.co.kr/62279 (accessed on 29 October 2019).

88. Pasquini, L.; Ziervogel, G.; Cowling, R.M.; Shearing, C. What enables local governments to mainstream climate change adaptation? Lessons learned from two municipal case studies in the Western Cape, South Africa. Clim. Dev. 2015, 7, 60-70. [CrossRef]

89. Ziervogel, G.; Shale, M.; Du, M. Climate change adaptation in a developing country context: The case of urban water supply in Cape Town. Clim. Dev. 2010, 2, 94-110. [CrossRef]

90. Harries, T.; Penning-Rowsell, E.C. Victim pressure, institutional inertia and climate change adaptation: The case of flood risk. Glob. Environ. Chang. 2011, 21, 188-197. [CrossRef]

91. McAndrews, C.; Deakin, E.; Schipper, L. Including climate change considerations in Latin American urban transport practices and policy agendas. J. Environ. Plan. Manag. 2013, 56, 674-694. [CrossRef]

92. Olhoff, A.; Schaer, C. Screening Tools and Guidelines to Support the Mainstreaming of Climate Change Adaptation into Development Assistance-A Stocktaking Report; UNDP: New York, NY, USA, 2010.

93. Picketts, I.M.; Werner, A.T.; Murdock, T.Q. Planning for climate change adaptation: Lessons learned from a community-based workshop. Environ. Policy 2012, 17, 82-93. [CrossRef]

(C) 2020 by the authors. Licensee MDPI, Basel, Switzerland. This article is an open access article distributed under the terms and conditions of the Creative Commons Attribution (CC BY) license (http://creativecommons.org/licenses/by/4.0/). 